\title{
Correction to: The effect of irrigation on malaria vector bionomics and transmission intensity in western Ethiopia
}

Werissaw Haileselassie ${ }^{1 \dagger}$, Endalew Zemene ${ }^{2^{*}{ }^{+}}$, Ming-Chieh Lee ${ }^{3}$, Daibin Zhong ${ }^{3}$, Guofa Zhou ${ }^{3}$, Behailu Taye ${ }^{4}$, Alemayehu Dagne4, Wakgari Deressa', James W. Kazura ${ }^{5}$, Guiyun Yan ${ }^{3}$ and Delenasaw Yewhalaw 2,6

\section{Correction to: Parasites Vectors (2021) 14: 516} https://doi.org/10.1186/s13071-021-04993-y

Following publication of the original article [1], it was brought to our attention that incorrect grant numbers had been provided in the funding declaration of the article.

The following grant numbers had been provided: "U19 AI089672 and D43 TW009527".

However, the correct grant numbers are as follows: "U19 AI129326 and D43 TW001505".

The original article has been updated to correct these numbers.

The authors thank you for reading this correction and apologize for any inconvenience caused.

\section{Author details}

${ }^{1}$ School of Public Health, College of Health Sciences, Addis Ababa University, Addis Ababa, Ethiopia. ${ }^{2}$ School of Medical Laboratory Sciences, Institute of Health, Jimma University, Jimma, Ethiopia. ${ }^{3}$ Program in Public Health,

\begin{abstract}
College of Health Sciences, University of California at Irvine, Irvine, CA 92697, USA. ${ }^{4}$ Department of Biology, Faculty of Natural and Computational Science, Mettu University, Mettu, Ethiopia. ${ }^{5}$ Center for Global Health and Disease, Case Western Reserve University, Cleveland, OH 44106, USA. ${ }^{6}$ Tropical and Infectious Diseases Research Centre, Jimma University, Jimma, Ethiopia.
\end{abstract}

Published online: 18 November 2021

\section{Reference}

1. Haileselassie W, Zemene E, Lee M-C, Zhong D, Zhou G, Taye B, Dagne A, Deressa W, Kazura JW, Yan G, Yewhalaw D. The effect of irrigation on malaria vector bionomics and transmission intensity in western Ethiopia. Parasites Vectors. 2021;14:516. https://doi.org/10.1186/ s13071-021-04993-y.

\section{Publisher's Note}

Springer Nature remains neutral with regard to jurisdictional claims in published maps and institutional affiliations. original author(s) and the source, provide a link to the Creative Commons licence, and indicate if changes were made. The images or other third party material in this article are included in the article's Creative Commons licence, unless indicated otherwise in a credit line to the material. If material is not included in the article's Creative Commons licence and your intended use is not permitted by statutory regulation or exceeds the permitted use, you will need to obtain permission directly from the copyright holder. To view a copy of this licence, visit http://creativecommons.org/licenses/by/4.0/. The Creative Commons Public Domain Dedication waiver (http://creativecommons.org/publicdomain/zero/1.0/) applies to the data made available in this article, unless otherwise stated in a credit line to the data. 